\title{
UM OLHAR ESTERIOTIPADO
}

WARDI AWADA CARDOSO DUVA

FACULDADE CÁSPER LIBERO

BELA VISTA, SÃO PAULO, SÃO PAULO

WAWADA@CARAS.COM.BR 


\section{UM OLHAR ESTERIOTIPADO}

Hall, Stuart. Cultura e Representação. Rio de Janeiro: Apicuri/Editora Puc -Rio, 2016

Nunca imaginei que ao ler um livro sobre representação teria as revelações que tive, sobre inúmeras passagens do que vivi em minha infância. Filha de libaneses, a primeira da família a nascer no Brasil, fui à escola com sete anos completos. Esses anos de basicamente convivência familiar, trouxeram-me um repertório cultural replicado daquilo que minha mãe, com quem passava meus dias, trazia consigo. Durante os primeiros tempos na escola fui classificada como "estranha". Não conhecia muitos dos provérbios e metáforas que os professores utilizavam. Para mim não faziam sentido, não tinham significado. Mas, a leitura de Cultura e Representação me fez compreender que a "cultura se relaciona a sentimentos, a emoções, a um senso de pertencimento, bem como a conceitos e ideias" (p. 20).

O tempo acabou por me agregar a cultura além dos muros da minha casa. Trouxe minha compreensão da representação e dos significados para o grupo cultural no qual estava me inserindo e o tal "senso de pertencimento". Isso porque:

Colocando em termos simples, cultura diz respeito a "significados compartilhados". Ora, a linguagem nada mais é do que o meio privilegiado pelo qual "damos sentido" às coisas, onde o significado é produzido e intercambiado. Significados só podem ser compartilhados pelo acesso comum a linguagem. Assim, esta se torna fundamental para os sentidos e para a cultura e vem sendo invariavelmente considerada o repositório-chave de valores e significados culturais. (Hall, 2016, p.17)

Dividido em dois capítulos, "O papel da Representação" e "O espetáculo do Outro", cada um deles traz subtítulos em que há atividades para fixação, leitura complementar de textos, imagens, contextualizações históricas, além de um pequeno resumo ao final. Na verdade, cada título é praticamente uma aula. Faz com que o leitor interprete num primeiro momento uma imagem ou situação a partir de seu próprio arcabouço de sensações, cultura, propondo perguntas que devem ser respondidas por meio da observação.

Para Hall "Representação é uma parte essencial do processo pelo qual os significados são produzidos e compartilhados entre membros de uma cultura" (p. 32). Cuida, então, de discorrer sobre diferentes teorias de como a linguagem é utilizada para representar o mundo. 
Para construir o conceito de representação, Hall apela à abordagem linguística de Ferdinand de Saussure, trazendo as noções de "signo" "significante" e "significado". Também são convocados os mitos teorizados por Roland Barthes e a abordagem discursiva da teoria de Michel Foucault, quando ele analisa não somente a linguagem, mas sua aplicação direcionada para o conhecimento e forma de poder. Hall trata de localizar o sujeito nas teorias de Saussure, Barthes e Foucault.

Se o primeiro capítulo se dedica a fazer o leitor entender o significado da representação e o lugar da representação no circuito cultural, o segundo capítulo trata, a partir do entendimento do leitor da teoria proposta no primeiro capítulo, da prática representacional, com enfoque na "estereotipagem".

Neste capítulo, o autor trata de temas como diferença e alteridade, da estereotipagem como prática representacional, o poder, hegemonia, poder/conhecimento e alguns efeitos inconscientes (fantasia, fetichismo, retratação).

Hall aprofunda o debate sobre raça para tratar de estereótipos e dedica grande parte dos exemplos às questões raciais ligadas aos negros. Contudo, no subcapítulo "Representação, diferença e poder" ( p.193), há trechos sobre o estudo de Edward Said, de como a Europa construiu a imagem estereotipada do "Oriente".

Citado por Hall, o estudo de Said afirma que "longe de simplesmente espelhar como os países do oriente médio eram de verdade, o 'orientalismo' foi o 'discurso' pelo qual a cultura europeia conseguiu administrar - e até produzir - o Oriente [...]" (p.194).

E novamente a leitura me traz clareza e entendimento, agora do Oriente estereotipado. Se o olhar de Said em 1978 mostrava a Europa estereotipando o Oriente, nos termos dos estudos de Hall, vejo a cultura americana inconformada com a resistência do Oriente à imposição de sua "mesmice cultural".

Obviamente, não se justifica violência e extremismo, porém, a narrativa da generalização de um povo, de uma religião que tenta manter a todo custo o que entende de sua identidade cultural, enquanto se sente oprimida por uma cultura que busca se impor pelo poder, promove o estereótipo, subjuga e não tolera, culmina em explosão, em revolta. Mas, certamente cada leitor encontrará suas identificações, seus próprios significados e seu estereótipo após a esclarecedora leitura. 


\section{Wardi Awada Cardoso Duva}

Mestranda Programa de Pós-Graduação em Comunicação da Faculdade Cásper Líbero. Formada em Direito/ Universidade Paulista/Pós-Graduada latu sensu em Processo Civil - PUC/SP. E-mail:wawada@caras.com.br. 